\title{
RACIAL ARCHITECTURE OF HUMAN MANDIBLE-AN ANTHROPOLOGICAL STUDY
}

Kishore Chandra Thakur¹, Alok Kumar Choudhary², Sanjeev Kumar Jain², Lalit Kumar.
1. Post Graduate Student, Department Of Anatomy, SGRRIM\&HS, Dehradun.
2. Lecturer, Department Of Anatomy, SGRRIM \& HS, Dehradun.
3. Professor \& Head of Department, Department Of Anatomy, SGRRIM \& HS, Dehradun.
4. Assistant Professor, Department of Forensic Medicine, SGRRIM \& HS, Dehradun.

\section{CORRESPONDING AUTHOR:}

Kishore chandra Thakur, House no. 26, Lane-2, Rajvihar, Chakrata Road, Dehradun 248001

E-mail: thakurdon@yahoo.com

\section{HOW TO CITE THIS ARTICLE:}

Kishore Chandra Thakur, Alok Kumar Choudhary, Sanjeev Kumar Jain, Lalit Kumar. "Racial architecture of Human Mandible- an Anthropological Study". Journal of Evolution of Medical and Dental Sciences 2013; Vol2, Issue 23, June 10; Page: 4177-4188.

ABSTRACT: Skeletal elements are used to quantify variations related to sexual dimorphism. Determination of sex and race in unknown skeletal remains is one of the key biological characteristics used. Mandible is next to pelvis in determination of sex, age and race. Methods based on cranio -mandibular parameters contribute for sex determination and race identification. The mandible is a U-shaped and the only mobile bone of the facial skeleton. The 2 sides of the mandible are not always perfectly symmetrical, due to inherent general asymmetry. AIM \& OBJECTIVE: The present study is an attempt to evaluate two important metric traits of the mandible like mandibular angle \& height of the ramus. It's role in sexual dimorphism, and as an anthropological tool in racial and / or population diagnosis of Indian origin, especially in Uttarakhand region. MATERIAL AND METHOD: 30 dry male and 30 dry female adult human mandibles collected from Departments of Anatomy and Forensic Medicine of SGRR Medical College. Well preserved mandibles with intact body, ramus, gonion and coronoid process used. Instrument used to measure is Mandibulometer. ANALYTICAL TEST: “t” test. RESULT: Mean mandibular angle of right side is 115.00 degree and on left side is 113.77 degree whereas ramus height of right side is $4.94 \mathrm{~cm}$ and on left side is $4.80 \mathrm{~cm}$. CONCLUSION: Significant difference in mean mandibular angle of right and left of female and not so in male. Significant difference was noted between the mean right and left ramus height of male and female respectively.

KEY WORDS: Mandibular angle, Ramus height, Mandibulometer, Racial identification

INTRODUCTION: Physical anthropologists traditionally study variations in the human skeleton with the use of metric and non-metric means (1). The use of physical morphology to catalogue individuals and populations is not a new phenomenon in anthropology (1-8). Usage of the term "race" in anthropology has been slowly discontinued in the last decade, largely because its use has 
fueled the idea that humankind can be separated into discrete categories. Instead, there has been growing use of the term "ancestry".

Mandible is next to pelvis in determination of sex, age and race $(9,10)$. The mandible is a Ushaped bone. It is the only mobile bone of the facial skeleton, and, since it houses the lower teeth, its motion is essential for mastication. The mandible is composed of 2 hemi mandibles joined at the midline by a vertical symphysis. The hemi mandibles fuse to form a single bone by age 2 years. Each hemi mandible is composed of a horizontal body with a posterior vertical extension termed the ramus (11). The ramus extends vertically in a postero superior direction posterior to the body on each hemi mandible. The mandibular angle is formed by the intersection of the inferior rim of the body and the posterior rim of the ascending ramus. The mandible houses the lower dentition, which in adults consists of 2 central and 2 lateral incisors, 2 canines, 2 first and 2 second premolars, and 3 sets of molars. Metric analysis involves taking measurements and applying discriminant functional analysis to measurements (11). A non-metric analysis has been criticized because of the subjectivity of the anthropologist's characterization of the traits in question, which may account for a high degree of inter-observer error (12). A non-metric trait refers to any trait that is not quantitatively measured but instead described on a continuous, quasi-continuous, or discrete categorical scale.

A long-standing controversy exists about the comparative utility of metric and non-metric traits as biological indicators in population studies. The discriminant analyses were performed using metric traits to discriminate between groups formed by non-metric trait presence or absence. Metric and non-metric traits share a moderate to high degree of developmental determination. The cause of these correlations may lie in the common effects that growth and development of the soft tissue and functional spaces of the cranium exert on both metric and non-metric traits (13). Results indicate that the adult mandible could be used to identify both sex and population affinity with increased sensitivity and objectivity compared to other standard analytical techniques (14). Furthermore, results show clearly that sex may even be determined from lower jaw fragments (15). Many studies show that mean mandibular angle and height are greater in females (about 128 degrees and $6.13 \mathrm{~cm}$ ) than in males (about 123.06 degrees and $5.98 \mathrm{~cm}$ ) of specified age of some race (22).

Some researchers $(16,17)$ questioned the reliability of using non-metric traits and advocated using exclusively metric means while others (18-21) found support for the theory that metric and non-metric data were linked. Corruccini (19) argued that non-metric traits contributed significantly to exploring genealogical and genetic relationships in populations but his research, like others $(18,20)$, was often inconclusive.

There is statistically significant sex difference in the mandibular angle and length in context to gender and race for example the average mandibular angle of the Black Zimbabweans is greater than the values reported for some Black African populations (22). According to Kieffer, individuals with short and broad faces (Chamaeprosopic) has smaller angle than individuals with a long and narrow face (Leptoprosopic) (23).

Anthropologists worked in different regions to evaluate the mandibular angle and to analyze the relationship of the angle and height \& breadth of the ramus of the mandible to the gender, so as to study its role in the anthropological diagnosis (24). 
The present study is an attempt to evaluate two important metric traits of the mandible like mandibular angle \& height of the ramus so as to study its role in sexual dimorphism, and as an anthropological tool in racial and / or population diagnosis of Indian origin, especially in Uttarakhand.

MATERIAL \& METHOD: 30 dry male and 30 dry female adult human mandibles (total 60) collected from Departments of Anatomy and Forensic Medicine of SGRR Medical College., Dehradun.

Mandibles included in study under following criteria (25):

1. Mandibles with intact body, ramus, gonion and coronoid process.

2. Adult mandibles included in study with following features:

a) Full eruption of molar.

b) Mid position of mental foramen between upper and lower borders of the body Mandibles with following features not included in study:

a) Damaged.

b) Higher/lower position of mental foramen

c) No eruption of molars

d) Mandible with any discrepancy in sex and age determination

Sex determination of mandibles done according to following criteria:

$\begin{array}{lll} & \text { MALE } & \text { FEMALE } \\ \text { 1) Gonial eversion } & \text { Marked } & \text { Slight/absent } \\ \text { 2) Chin } & \text { Square } & \text { Pointed/rounded } \\ \text { 3) Robustness } & \text { Larger, broader } & \text { Slender, smaller } \\ & \text { Thicker, heavier } & \end{array}$

In males the lateral aspect of the angle of the mandible shows rough or rigid appearance. In females the angle of the jaw is often more rounded and gracile in construction. The attachment surface of the masseter muscle is often much smoother (26-28).

Variables measured and instrument used: The mandibular angles, ramus height of mandible measured on both right and left sides of each mandible of male and female.

Mandibular Angle: angle formed by the inferior border of the corpus and the posterior border of the ramus. Instrument: Mandibulometer

Maximum Ramus Height: direct distance from the highest point on the mandibular condyle to gonion. Instrument: Mandibulometer (23) 


\section{ORIGINAL ARTICLE}

\section{FEMALE MANDIBLE}

\begin{tabular}{|c|c|c|c|c|}
\hline & Right side & Right side & Left side & Left side \\
\hline Serial no. & $\begin{array}{c}\text { ANGLE } \\
\text { (IN DEGREE) }\end{array}$ & $\begin{array}{l}\text { R.HEIGHT } \\
\text { (IN C.M.) }\end{array}$ & $\begin{array}{c}\text { ANGLE } \\
\text { (IN DEGREE) }\end{array}$ & $\begin{array}{l}\text { R.HEIGHT } \\
\text { (IN C.M.) }\end{array}$ \\
\hline 1 & 112 & 4.1 & 112 & 4.5 \\
\hline 2 & 115 & 3.9 & 119 & 4.1 \\
\hline 3 & 123 & 3.8 & 115 & 4.3 \\
\hline 4 & 96 & 2.8 & 98 & 3.0 \\
\hline 5 & 109 & 5.3 & 107 & 4.8 \\
\hline 6 & 123 & 3.9 & 123 & 4.3 \\
\hline 7 & 107 & 4.1 & 105 & 4.7 \\
\hline 8 & 113 & 4.8 & 110 & 5.0 \\
\hline 9 & 110 & 4.3 & 112 & 4.1 \\
\hline 10 & 102 & 3.8 & 102 & 3.9 \\
\hline 11 & 124 & 4.8 & 105 & 8.1 \\
\hline 12 & 111 & 3.8 & 105 & 3.4 \\
\hline 13 & 112 & 3.7 & 109 & 2.8 \\
\hline 14 & 109 & 3.0 & 109 & 2.6 \\
\hline 15 & 127 & 3.4 & 93 & 3.3 \\
\hline 16 & 124 & 2.7 & 116 & 3.0 \\
\hline 17 & 115 & 6.1 & 112 & 3.0 \\
\hline 18 & 115 & 5.1 & 109 & 2.6 \\
\hline 19 & 125 & 3.8 & 93 & 3.3 \\
\hline 20 & 99 & 6.4 & 109 & 3.5 \\
\hline 21 & 115 & 5.3 & 119 & 3.0 \\
\hline 22 & 125 & 5.3 & 118 & 3.0 \\
\hline 23 & 120 & 4.5 & 98 & 3.4 \\
\hline 24 & 105 & 6.0 & 118 & 3.0 \\
\hline 25 & 120 & 4.5 & 98 & 3.4 \\
\hline 26 & 105 & 6.0 & 105 & 2.9 \\
\hline 27 & 112 & 5.0 & 125 & 3.0 \\
\hline 28 & 122 & 5.7 & 105 & 3.5 \\
\hline 29 & 112 & 6.1 & 108 & 3.3 \\
\hline 30 & 115 & 5.4 & 109 & 2.8 \\
\hline
\end{tabular}

TABLE : I

KEYS:

R-RAMUS

C.M.-CENTIMETER 


\section{ORIGINAL ARTICLE}

\section{MALE MANDIBLE}

\begin{tabular}{|c|c|c|c|c|}
\hline & Right side & Right side & Left side & Left side \\
\hline $\begin{array}{c}\text { Serial } \\
\text { no. }\end{array}$ & $\begin{array}{c}\text { ANGLE } \\
\text { (IN DEGREE) }\end{array}$ & $\begin{array}{l}\text { R.HEIGHT } \\
\text { (IN C.M.) }\end{array}$ & $\begin{array}{c}\text { ANGLE } \\
\text { (IN DEGREE) }\end{array}$ & $\begin{array}{l}\text { R.HEIGHT } \\
\text { (IN C.M.) }\end{array}$ \\
\hline 1 & 111 & 6.7 & 118 & 7.0 \\
\hline 2 & 127 & 6.1 & 134 & 6.7 \\
\hline 3 & 110 & 5.7 & 118 & 5.8 \\
\hline 4 & 109 & 5.6 & 118 & 6.1 \\
\hline 5 & 103 & 4.4 & 117 & 5.0 \\
\hline 6 & 119 & 4.2 & 129 & 5.5 \\
\hline 7 & 133 & 3.2 & 141 & 4.1 \\
\hline 8 & 118 & 5.3 & 124 & 5.5 \\
\hline 9 & 126 & 5.2 & 134 & 5.0 \\
\hline 10 & 122 & 4.2 & 129 & 5.2 \\
\hline 11 & 117. & 4.8 & 114 & 6.8 \\
\hline 12 & 120 & 6.2 & 118 & 7.4 \\
\hline 13 & 104 & 6.5 & 103 & 7.5 \\
\hline 14 & 112 & 6.2 & 109 & 7.0 \\
\hline 15 & 107 & 6.6 & 103 & 6.4 \\
\hline 16 & 134 & 4.3 & 133 & 5.6 \\
\hline 17 & 122 & 4.1 & 123 & 6.3 \\
\hline 18 & 107 & 5.6 & 105 & 6.7 \\
\hline 19 & 120 & 5.5 & 117 & 6.3 \\
\hline 20 & 103 & 6.2 & 99 & 7.2 \\
\hline 21 & 119 & 5.2 & 115 & 6.8 \\
\hline 22 & 124 & 4.5 & 124 & 4.9 \\
\hline 23 & 126 & 4.9 & 128 & 5.1 \\
\hline 24 & 115 & 4.6 & 118 & 4.8 \\
\hline 25 & 111 & 4.8 & 112 & 4.5 \\
\hline 26 & 118 & 5.0 & 120 & 4.9 \\
\hline 27 & 110 & 5.5 & 115 & 5.7 \\
\hline 28 & 108 & 4.5 & 112 & 4.6 \\
\hline 29 & 108 & 6.8 & 112 & 7.0 \\
\hline 30 & 115 & 6.5 & 118 & 6.7 \\
\hline
\end{tabular}

Table: II

KEYS:

R-RAMUS

\section{C.M.-CENTIMETER}




\section{ORIGINAL ARTICLE}

STATISTICAL ANALYSIS:

TABLE: III Analysis of angle and ramus height (each side) of Male \& Female

\begin{tabular}{|l|l|l|l|l|l|l|}
\hline \multirow{2}{*}{ Variable } & \multicolumn{3}{|c|}{ Female } & \multicolumn{2}{c|}{ Male } \\
\cline { 2 - 7 } & Mean & \multicolumn{1}{|c|}{$\begin{array}{c}\text { Standard } \\
\text { Deviation }\end{array}$} & $\begin{array}{c}\text { Standard } \\
\text { Error }\end{array}$ & Mean & $\begin{array}{c}\text { Standard } \\
\text { Deviation }\end{array}$ & $\begin{array}{c}\text { Standard } \\
\text { Error }\end{array}$ \\
\hline Angle - Right & 114.07 & \pm 8.12 & 1.48 & 115.93 & \pm 8.49 & 1.55 \\
\hline Angle - Left & 108.87 & \pm 8.17 & 1.49 & 118.67 & \pm 10.00 & 1.83 \\
\hline $\begin{array}{l}\text { Ramus Height } \\
\text { - Right }\end{array}$ & 4.58 & \pm 1.04 & 0.19 & 5.30 & \pm 0.93 & 0.17 \\
\hline $\begin{array}{l}\text { Ramus Height } \\
\text { - Left }\end{array}$ & 3.65 & \pm 1.08 & 0.20 & 5.94 & \pm 0.97 & 0.18 \\
\hline
\end{tabular}

TABLE: IV Overall analysis of variables of each side irrespective of gender

\begin{tabular}{|l|c|c|c|}
\hline \multicolumn{1}{|c|}{ Variable } & \multicolumn{3}{c|}{ Overall } \\
\cline { 2 - 4 } & Mean & Standard Deviation & Standard Error \\
\hline Angle - Right & 115.00 & \pm 8.29 & 1.07 \\
\hline Angle - Left & 113.77 & \pm 10.31 & 1.33 \\
\hline Ramus Height - Right & 4.94 & \pm 1.04 & 0.13 \\
\hline Ramus Height - Left & 4.80 & \pm 1.54 & 0.20 \\
\hline
\end{tabular}

\section{RESULTS:}

1. There is no significant difference between the mean angle of right measurement of male and female mandibles applying Independent samples ' $\mathrm{t}$ ' test when level of significance is 0.05 , $\mathrm{SD}(\mathrm{F})= \pm 8.12, \mathrm{SD}(\mathrm{M})= \pm 8.45, \mathrm{SE}(\mathrm{F})=1.48, \mathrm{SE}(\mathrm{M})=1.55$.

2. There is evidence that suggests there is significant difference between the mean angle of left measurement of male and female mandibles applying Independent samples ' $\mathrm{t}$ ' test when level of significance is $0.05, \mathrm{SD}(\mathrm{F})= \pm 8.17, \mathrm{SD}(\mathrm{M})= \pm 10.00, \mathrm{SE}(\mathrm{F})=1.49, \mathrm{SE}(\mathrm{M})=1.83$

3. There is a significant difference between the mean height of right ramus of male and female mandibles applying Independent samples ' $\mathrm{t}$ ' test when level of significance is 0.05 , SD $(F)= \pm 1.04, \operatorname{SD}(M)= \pm 00.93, \mathrm{SE}(\mathrm{F})=0.19, \mathrm{SE}(\mathrm{M})=0.17$

4. There is a significant difference between the mean height of left ramus of male and female mandibles applying Independent samples ' $\mathrm{t}$ ' test when level of significance is 0.05 , SD $(F)= \pm 1.08, \operatorname{SD}(M)= \pm 00.97, \operatorname{SE}(F)=0.20, \mathrm{SE}(\mathrm{M})=0.18$.

5. There is a significant difference between the mean left and right angles of female mandibles applying Independent samples ' $\mathrm{t}$ ' test when level of significance is $0.05, \mathrm{SD}(\mathrm{L})= \pm 8.17$, $\mathrm{SD}(\mathrm{R})= \pm 8.12, \mathrm{SE}(\mathrm{L})=1.49, \mathrm{SE}(\mathrm{R})=1.48$ 
6. There is a significant difference between the mean left and right ramus height of female mandibles applying Independent samples ' $\mathrm{t}$ ' test when level of significance is 0.05 , $\mathrm{SD}(\mathrm{L})= \pm 1.08, \mathrm{SD}(\mathrm{R})= \pm 1.04, \mathrm{SE}(\mathrm{L})=0.20, \mathrm{SE}(\mathrm{R})=0.19$

7. There is no significant difference between the mean left and right angles of male mandibles applying Independent samples ' $\mathrm{t}$ ' test when level of significance is $0.05, \mathrm{SD}(\mathrm{L})= \pm 10.00$, $\mathrm{SD}(\mathrm{R})= \pm 8.49, \mathrm{SE}(\mathrm{L})=1.83, \mathrm{SE}(\mathrm{R})=1.55$

8. There is a significant difference between the mean left and right ramus height of male mandibles applying Independent samples ' $\mathrm{t}$ ' test when level of significance is 0.05 , $\operatorname{SD}(\mathrm{L})= \pm 0.97, \operatorname{SD}(\mathrm{R})= \pm 0.93, \mathrm{SE}(\mathrm{L})=0.18, \mathrm{SE}(\mathrm{R})=0.17$

\section{SD: Standard Deviation SE: Standard Error R: Right L: Left F: Female M: Male}

DISCUSSION: Gender specific mandibular features make the sex identification possible and reliable in cases with damaged and partially preserved mandibles. It is of special importance for archaeological and forensic work to establish population-specific standards for sex determination from mandibles of unknown skulls. The gonial angle in man may vary from 100 degrees to 148 degrees. Its mean angle is highest in Caucasians, nearly as high in Chinese, Eskimos, and Negroes, and lowest in early Caucasians, Australian, and American Indians (23).

Present study suggestive of mean mandibular angle in female 114.07 degree on right side and 108.87 degree on left side. Whereas mean mandibular angle in male is 115.93 degree on right side and 118.67 degree on left side. Mandibular angle measured in female is from 96 to 127 degree and of male ranging 103 to 134 degree. According to Martin (Table V) mean mandible angle in CHINESE are 119 degree, in AFRICANS 120 degree.

\section{TABLE V: Mandible angles in different race}

\begin{tabular}{|l|l|l|}
\hline Population & $\begin{array}{l}\text { Mandible angle } \\
\text { (in degree) }\end{array}$ & Author \\
\hline Chinese & 119 & Martin 1928 \\
\hline African negroes & 120 & Martin 1928 \\
\hline North Indians & 119 & Rajalakshmi Rai 2007 \\
\hline Uttarakhand & 114.3 & Present study \\
\hline
\end{tabular}

According to Mbajiorgu et al. the mean mandibular angle and height were greater in females $\left(128^{\circ}\right.$ and $\left.6.13 \mathrm{~cm}\right)$ than in males $\left(123.06^{\circ}\right.$ and $\left.5.98 \mathrm{~cm}\right)(22)$. The present study shows that the mandibular angle is greater in males $\left(117.3^{\circ}\right)$ than that of females $\left(111.3^{\circ}\right)$, whereas the height of the male mandibular ramus $(5.62 \mathrm{~cm})$ is greater than that of female mandible $(4.11 \mathrm{~cm})$. Rajalakshmi Rai et al (24) found mean mandible angle in Indian population was about 119 degree, if considered according to gender then for male it was 118 degree and for female was 121 degree. Ramus height of male was about $5.39 \mathrm{~cm}$ and in female it was $5.18 \mathrm{~cm}$. 


\section{ORIGINAL ARTICLE}

TABLE VI: Comparative results of Indian origin

\begin{tabular}{|l|l|l|}
\hline Population & $\begin{array}{l}\text { Mandibular Angle } \\
\text { (in degree) }\end{array}$ & $\begin{array}{l}\text { Ramous Height } \\
\text { (in centimetre) }\end{array}$ \\
\hline Indian & 118 (Male) & 5.39 (Male) \\
\hline & 121 (Female) & 5.18 (Female) \\
\hline Uttarakhand & 117.3 (Male) & 5.62 (Male) \\
\hline & 111.3 (Female) & 4.11 (Female) \\
\hline
\end{tabular}

Ancestry significantly affects the measurements of bigonial width, mandibular length, mandibular angle, and minimum ramus breadth. Europeans have slightly larger bigonial width than Africans. This discrepancy may be due to Africans having stronger muscle attachments at the gonia and therefore creating more eversion. Europeans have a shorter mandible, more obtuse gonial angle, and a thinner mandibular ramus width than Africans (29). Ingervall and Thilander (30) have shown that dentate subjects with strong masseter and anterior temporal muscles have small gonial angles. Okeson (31) stress the fact that the forces of the elevator muscles attain their highest in young adults, and takes part in modeling the mandibular ramus which in turn contribute in the development of the mandibular ramus flexure. Konigsberg \& Hens (32) reported that a combination of five morphological cranial traits provides an accuracy of $81 \%$ in sex determination.

It has been stated that panoramic radiographs are accurate in determining the gonial angle and there is no significant difference between the rights and left sides in panoramic radiography (33).On the contrary, some researchers found that the gonial angle on the right side was significantly smaller than on the left possibly because of more use of the right side. In their study, most subjects reported that they chewed more often on the right side $(34,35)$.

There is compensatory hypertrophy in the area of muscle insertion due to the increase of the muscle size and tension. Prominence of the mandibular angle and bone spur development was detected. CT and MRI scans showed well-developed left masseter muscle with hypertrophy when compared to the right side. With a relatively greater facial height the angle is more obtuse (for example, open-bite); conversely, with a relatively smaller facial height it is more acute (for example, deep overbite) (23).

Infant and adult dimorphism of the mental region may be associated with the development of supralaryngeal structures (36). Specific bony aspects of the mandible change in both men and women and what implications of these structural changes may have on the techniques used in facial cosmetic surgery(37) .Study suggests that among Indonesians, maximum bite force could be explained by craniofacial morphology as found in Caucasians (38).

A definite increase in difficult laryngoscopy was observed when the mandibular angle tended to be more rostral. Impacted third molars increases the risk of mandibular angle fractures and decrease the risk of condylar fractures due to inherent weakness in the angle area with impacted teeth (39).

Orthodontic measures and procedures in jaw surgeries always require thorough radiographic investigations. The procedures generally employed are orthopantamography and cephalostatic examination (40).

Dental restorations and occlusal adjustments to correct premature contacts and malocclusions are important. Para functional habits must be prevented. In this case, patients may undergo a cosmetic surgery to reduce the bone prominence from the mandibular angle (41). In 
osteometric technique, data collection is time consuming, lengthy procedure and chances of error are always there due to lack in level of accuracy of method and device.

Currently, the development of computed tomographic and medical imaging techniques is widely accepted as a standard protocol for clinical diagnosis and surgical treatment planning. It enables 3D reconstruction and assesses craniofacial morphometric data both inner and outer anatomical landmark for the cranio-metric study (42-45).

Mandibular angle in conjunction with other anthropological parameters may be useful as anthropological tools in racial and / or population diagnosis. The findings of this study might be useful in providing anthropological data that can also be used in dental and medical practice.

ACKNOWLEDGEMENT: Article in hand owes its existence to the blessings of GOD and the learned guidance of my teachers. I have no words to express my feelings for my esteemed teachers in Department of Anatomy, SGRRIM\&HS, Dehradun for their constant supervision, excellent guidance and active encouragement throughout the course of study. I shall forever be indebted to them for showing me right path. The magnificent experience of working under them will be cherished lifelong in my fondest of remembrances.

I pay my sincere thanks to statiscian for helping me in statistical analysis.

I pay my sincere thanks to the technician in our anthropology lab, who helped me at every step throughout my work.

My existence in this world is due to my parents so I pay special thanks to them on this opportunity.

I pay my sincere thanks to my colleagues and friends for their help during this work. I dedicate this work to my Wife (Tarang) and Daughter (Sara) who stood as pillar and gave energy to continue my study.

\section{REFERENCES:}

1. Rhine S. Non metric skull racing. In: Gill G, Rhine s, editors. Skeletal attribution of race: Methods for Forensic Anthropology. Maxwell Museum of Anthropological Papers No. 4. Albuquerque (NM): University of New Mexico; 1990.p 1-7.

2. Birdsell, JB. Some Reflections on Fifty Years in Biological Anthropology Annual Review of Anthropology.1987; 16(1):1-13.

3. Howells, WW. Skull Shapes and the Map: Craniometric Analyses in the Dispersion of Modern Homo. Papers of the Peabody Museum of Archaeology and Ethnology 1989; 79:1-189.

4. Sauer, NJ. Forensic Anthropology and the Concept of Race: If races don't exist, why are forensic anthropologists so good at identifying them? Social Science \& Medicine 1992; 34(2): 107-111.

5. Harris, M. the Rise of Anthropological Theory (Updated Edition). USA (NY): Altamira Press; 2001.

6. Brues AM. The once and future diagnosis of race. In Gill G, Rhine S, editors. Skeletal attribution of race: Methods for Forensic Anthropology. Maxwell Museum of Anthropological Papers No. 4.Albuquerque (NM): University of New Mexico; 1990.p 1-7.

7. Brasili P, Zaccagni L, and Gualdi-Russo E. Scoring of non-metric cranial traits: a population study. Journal of Anatomy.1999; 195(4): 551-562. 
8. Relethford, JH. Race and Global Patterns of Phenotypic Variation. American Journal of Physical Anthropology .2009; 139(1):16-22.

9. Datta AK. Essentials of Human Anatomy part - II (Head and Neck), 5th ed. Calcutta: current book international; 2009. p 40-4.

10. Inderbir Singh. Text book of human osteology, 3rd ed.New Delhi: Jaypee Brothers Medical Publisher; 2009.p198-203.

11. Trotter M. Estimation of stature from intact long limb bones. In: Personal Identification in Mass Disasters. T. D. Stewart, ed. National Museum of Natural History, Washington (DC). 1970; p 71-83.

12. Church MS. Determination of race from the skeleton through Forensic Anthropological methods Forensic Sci. Rev. 1995; 7: 2-39

13. Cheverud, J. M., Buikstra, J. E. and Twichell, E. Relationships between non-metric skeletal traits and cranial size and shape. Am. J. Phys. Anthropol.1979, 50: 191-198. doi: 10.1002/ajpa.1330500207

14. Franklin D, Higginis P, Charles E \& Dadour I .Sexual dimorphism and population variation in the adult mandible, Forensic application of geometric morphometric. Forensic Science, Medicine and Pathology. 1996;3(1): 15-22

15. Potsch-Schneider L, Endris R, Schmidt H, Discriminant analysis of the mandible for sex determination. Journal of Legal Medicine,1985; 94(1): 21-30

16. Howells, WW. Cranial Variation in Man. A Study by Multivariate Analysis of Patterns of Differences among Recent Human Populations. Papers of the Peabody Museum of Archeology and Ethnology. Cambridge; Peabody Museum.1973;67:p259

17. Rightmire GP. Cranial measurements and discrete traits compared in distance studies of African Negro skulls. Human Biology 1972;44: 263-276

18. Carpenter J. C. A comparative study of metric and non-metric traits in a series of modern crania. Am. J. Phys. Anthropology. 1976; 45: 337-343. doi: 10.1002/ajpa.1330450219

19. Corruccini RS. The interaction between Non-metric and metric cranial variation. American Journal of Physical Anthropology 1976; 44(2):285-294.

20. Ossenberg NS. Within and Between Race Distances in Population Studies Based on Discrete Traits of the Human Skull. American Journal of Physical Anthropology 1976;45: 701-716

21. Trinkhaus E. Bilateral asymmetry of human skeletal non-metric traits. American Journal of Physical Anthropology.1978; 49(3): 215-218

22. Mbajiorgu F. E., Zivanovic S., Asala S. A., \& Mawera G.A pilot study of the mandibular angle in black Zimbabweans. The Central African journal of medicine .1996; 42(10):285-7.

23. Jensen E., \& Palling, M. The gonial angle: A survey. American Journal of Orthodontics 1954; 40(2): 120-133.

24. Rai R.; Ranade V. A.; Prabh, L V.; Pai, M. M.; Madhyasta, S. \& Kumaran, M. A Pilot study of mandible angle and ramous in Indian population.Int.J.Morphol.2007;25(2):353-356

25. Lockhart RD. Anatomy of the human skeleton, 2nd ed. London, Edward Arnold Publisher; 1965. p. 52.

26. Broth well DR. Digging up bones. 3rd.ed.New York: Cornell University Press; 1981. p. 82-95.

27. Prakash M. Sexual dimorphism measurements. Journal of Anatomical Society of India. 1987; 36: 45 
28. Whittaker DK.A color Atlas of forensic dentistry. $1^{\text {st }}$ ed. England: Wolfe Medical publications Ltd.; 1989. p.2-16

29. Morant GM. A First Study of the Tibetan Skull. 1923; 14(3-4): 193-260. doi:10.1093/biomet/14.3-4.193

30. Ingervall B, Thilander B. Relation between facial morphology and activity of masticatory muscles. J Oral Rehabil. 1974; 1:131-47

31. Okeson JP. History and examination of temporomandibular disorders. In: JP Okeson, editor. Occlusion treatment and temporomandibular disorders. May5. 르 ed. Madrid: Elsevier; 2003. p. 245-320.

32. Konigsberg LW, Hens SM. Use of ordinal categorical variables in skeletal assessment of sex from the cranium. Am. J. Phys. Anthropology. 1998; 107: 97-112

33. Larheim TA, Svanaes DB. Reproducibility of rotational panoramic radiography: Mandibular linear dimensions and angles. Am J Orthod Dentofac Orthop 1986; 90: 45-51.

34. ) De Sousa JC, Machado FA, Porto Silva, PA, Cardinot TM, Babinski MA. Correlation of the gonial angle with condylar measurements on dry mandible: a morphometric study for clinical-surgical and physiotherapeutic practices. Eur J Anat 2006; 10: 91-96

35. Bakke M, Holm B, Kensen BL, Michler L, Moller E. Unilateral, isometric bite force in 8-68year-old women and men related to occlusal factors. Scand J Dent Res .1990; 98: 149-58

36. Coquerelle M.,Bookstein F. L., Braga J., Halazonetis D. J., Weber G. W. and Mitteroecker P. Sexual dimorphism of the human mandible and its association with dental development.Am.J. Phys. Anthropol.2011; 145: 192-202.

37. Shaw Jr, R. B., Katzel E. B., Koltz P. F., Kahn D. M., Girotto J. A., \& Langstein H. N.Aging of the mandible and its aesthetic implications. Plastic and reconstructive surgery.2010; 125(1): 332-342

38. Sondang P, Kumagai H, Tanaka E, Ozaki H, Nikawa H, Tanne K. and Hamada T. Correlation between maximum bite force and craniofacial morphology of young adults in Indonesia. Journal of Oral Rehabilitation .2003; 30: 1109-1117.

39. Duan D. H, Zhang Y. Does the presence of mandibular third molars increase the risk of angle fracture and simultaneously decrease the risk of condylar fracture?. International journal of oral and maxillofacial surgery, 2008; 37(1): 25-28.

40. Mattila $\mathrm{K}$, Altonen $\mathrm{M}$, Haavikko $\mathrm{K}$. Determination of the gonial angle from the orthopantomogram. The Angle orthodontist,1977; 47(2):107-110

41. Waldhart E, Lynch JB. Benign hypertrophy of the masseter muscles and mandibular angles. Arch Surg .1971;152:115

42. BNS, Y. K., DEng, K. S. Craniometric study of Thai skull based on three-dimensional computed tomography (CT) data. J Med Assoc Tha. 2010; 93(1): 90-8.

43. Park SH, Yu HS, Kim KD, Lee KJ, Baik HS. A proposal for a new analysis of craniofacial morphology by 3-dimensional computed tomography. Am J Orthod Dentofacial Orthop. 2006; 129:600-34.

44. Hwang HS, Hwang CH, Lee KH, Kang BC.Maxillofacial 3-dimensional image analysis forthe diagnosis of facial asymmetry. Am J Orthod Dentofacial Orthop. 2006; 130: 779-85.

45. Cavalcanti MG, Rocha SS, Vannier MW.Craniofacial measurements based on 3D-CT Volume rendering: implications for clinical applications. Dentomaxillofac Radiol .2004; 33:170-6. 


\section{ORIGINAL ARTICLE}

PHOTOGRAPH: MANDIBULOMETER (MEASURING ANGLE AND RAMUS HEIGHT)

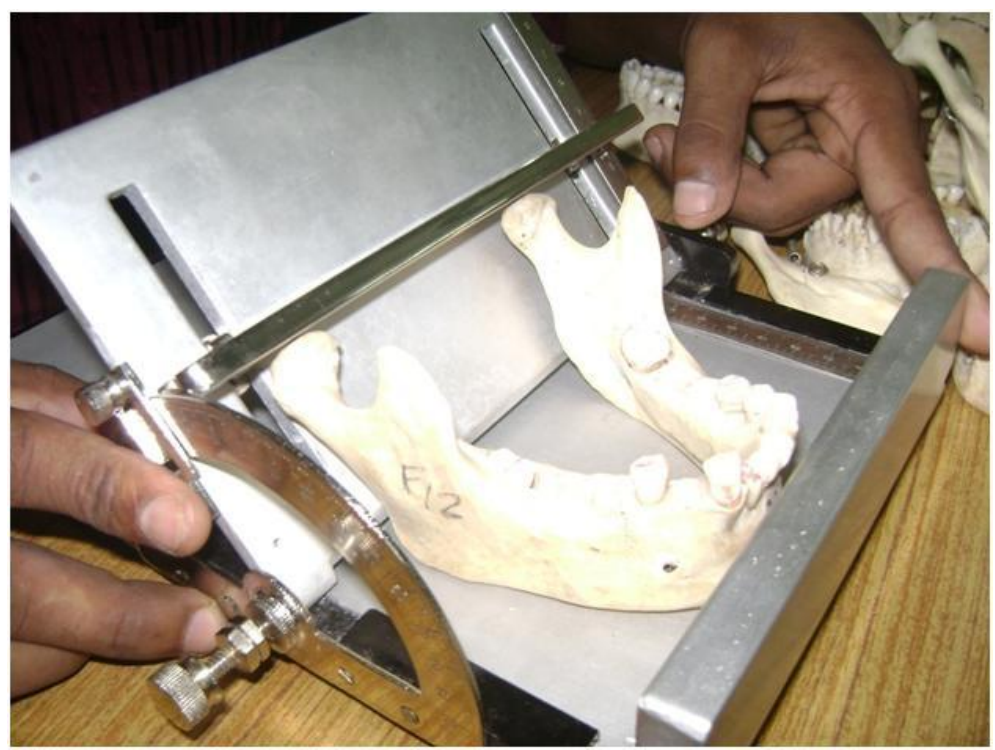

